\title{
Effects of cortisol and oestradiol on hepatic 11ß-hydroxysteroid dehydrogenase type 1 and glucocorticoid receptor proteins in late-gestation sheep fetus
}

\author{
S Gupta ${ }^{1}$, N Alfaidy ${ }^{1}$, A C Holloway ${ }^{1}$, W L Whittle ${ }^{1}$, S J Lye ${ }^{1}$, \\ W Gibb ${ }^{2}$ and J R G Challis ${ }^{1}$ \\ ${ }^{1}$ CIHR Institute of Human Development, Child and Youth Health, Departments of Physiology, and Obstetrics and Gynecology, University of Toronto,
Canada M5S 1A8
${ }^{2}$ CIHR Institute of Human Development, Child and Youth Health, Departments of Cellular and Molecular Medicine, and Obstetrics and Gynecology,
University of Ottawa, Ottawa, Canada K1H 8L6.
(Requests for offprints should be addressed to S Gupta, Department of Physiology, University of Toronto, 1 King's College Circle, Medical Sciences Building
Room 3344, Toronto, Ontario M5S 1A8, Canada; Email: shalini.gupta@utoronto.ca)
}

\begin{abstract}
In the late-gestation sheep, increased fetal plasma cortisol concentration and placental oestradiol $\left(\mathrm{E}_{2}\right)$ output contribute to fetal organ maturation, in addition to the onset of parturition. Both cortisol and $\mathrm{E}_{2}$ are believed to regulate the enzyme $11 \beta$-hydroxysteroid dehydrogenase type 1 (11ß-HSD1), which interconverts bioactive 11-hydroxy glucocorticoids and their inactive 11-keto metabolites. $11 \beta-H S D 1$, abundantly expressed in fetal liver, operates primarily as a reductase enzyme to produce bioactive cortisol and thus regulates local hepatic glucocorticoid concentrations. Cortisol acts through the glucocorticoid receptor (GR) present in the liver. In this study, we examined the effects of cortisol and $\mathrm{E}_{2}$ on hepatic $11 \beta$ HSD 1 and GR in the liver of chronically catheterized sheep fetuses treated with saline $(n=5)$, cortisol $(1.35 \mathrm{mg} /$ $\mathrm{h} ; \quad n=5)$, saline +4-hydroxyandrostendione, a P450 aromatase inhibitor (4-OHA; $1.44 \mathrm{mg} / \mathrm{h} ; n=5)$, or cortisol+4-OHA $(n=5)$. Cortisol infusion resulted in increased plasma concentrations of fetal cortisol and $\mathrm{E}_{2}$; concurrent administration of 4-OHA attenuated the
\end{abstract}

increase in plasma $\mathrm{E}_{2}$ concentrations. Using immunohistochemistry, we showed that fetal hepatocytes expressed both $11 \beta-\mathrm{HSD} 1$ and GR proteins. Cortisol treatment increased GR in both cytosol and nuclei of hepatocytes; concurrent administration of 4-OHA was associated with distinct nuclear GR staining. Western blot revealed that cortisol, in the absence of increased $\mathrm{E}_{2}$ concentrations, significantly increased concentrations of $11 \beta-H S D 1(34 \mathrm{kDa})$ and GR $(95 \mathrm{kDa})$ proteins. 11 $\beta-$ HSD1 enzyme activity was measured in the liver microsomal fraction in the presence of $\left[{ }^{3} \mathrm{H}\right]$ cortisone $\left(10^{-6} \mathrm{M}\right)$ or $\left[{ }^{3} \mathrm{H}\right]$ cortisol $\left(10^{-6} \mathrm{M}\right)$ and NADPH (reductase activity) or $\mathrm{NADP}^{+}$(dehydrogenase activity) respectively. $11 \beta-$ HSD1 reductase activity was significantly greater in the presence of cortisol. In summary, we found that, in sheep during late gestation, cortisol increased both $11 \beta$ HSD1 and GR in the fetal liver, and these effects were accentuated in the absence of increased $\mathrm{E}_{2}$.

Journal of Endocrinology (2003) 176, 175-184

\section{Introduction}

It is well established that parturition in the sheep is dependent on activation of the fetal hypothalamicpituitary-adrenal axis during late gestation and a concurrent increase in fetal plasma cortisol concentrations (Bassett \& Thorburn 1969, Liggins 1976, Thorburn \& Challis 1979). There is also an increase in production of oestradiol $\left(E_{2}\right)$ from the placenta that follows the increase in circulating glucocorticoid concentrations (Challis \& Brooks 1989). During late pregnancy, fetal cortisol plays a major part in maturation of several fetal organ systems, including the lung, liver, kidneys and gut (Fowden et al. 1998). In the fetal liver, glucocorticoids regulate hepatic functions, including lipid and carbohydrate metabolism (Silver 1990, Jamieson et al. 1999). Cortisol reaches the liver from the systemic circulation, or may be produced locally under the influence of the enzyme $11 \beta$-hydroxysteroid dehydrogenase $(11 \beta-H S D)$. The regulation of hepatic $11 \beta-H S D$ in fetal life, and its contribution to bioactive glucocorticoid production in the fetal liver, are currently unknown.

$11 \beta-H S D$ is a microsomal enzyme responsible for the interconversion of physiologically active glucocorticoids (cortisol in many species, including sheep and human; corticosterone in rodents) with their inactive 11-keto metabolites (cortisone in many species, including sheep 
and human; 11-dehydrocorticosterone in rodents), thus regulating the access of active glucocorticoids to their receptors (Monder \& White 1993). Two distinct types of $11 \beta-H S D$ have been cloned and characterized (Rusvai \& Naray-Fejes-Toch 1993, Yang \& Yu 1994, Brown et al. 1996). 11 $\beta$-HSD type 1 is a reversible NADP/NADPHdependent isoenzyme that catalyses the interconversion of physiologically active cortisol and its inactive metabolite cortisone (Stewart \& Krozowski 1999). In comparison, $11 \beta$-HSD type 2 is a unidirectional $\mathrm{NAD}^{+}$-dependent dehydrogenase that converts cortisol to cortisone (Rusvai \& Naray-Fejes-Toth 1993). Thus the expression of $11 \beta$ HSD isoenzymes and the direction of activity may be important in the local regulation of corticosteroid concentrations within glucocorticoid target tissues (Whorwood et al. 1993, Rajan et al. 1996) such as liver (Tannin et al. 1991, Jamieson et al. 1995, Tomlinson \& Stewart 2001), lung (Hundertmark et al. 1995, Wood \& Srun 1995), placenta (Yang et al. 1997), adipose tissue (Bujalska et al. 1997, Rask et al. 2001), gonad (Ricketts et al. 1998b) and the central nervous system (Kim et al. 1995). In the fetal sheep liver 11 $\beta$-HSD1 was highly expressed, whereas $11 \beta-H S D 2$ mRNA and activity were undetectable (Yang et al. 1992). 11 $\beta$-HSD1 has a greater affinity for cortisone than cortisol, and generally acts in the reductase direction to produce cortisol from cortisone. Although some dehydrogenase activity has been detected in the fetal liver (Jamieson et al. 2000), the net production of bioactive cortisol predominates (Yang et al. 1995, Ricketts et al. 1998a).

Local cortisol exerts its actions via the glucocorticoid receptor (GR) expressed in glucocorticoid target tissues. The liver expresses relatively high numbers of receptors (Raddatz et al. 1996). In the ligand-unbound state, GR is found in the cytosol bound to a complex of heat shock proteins and other stabilizing molecules (Bamberger et al. 1996, Galigniana et al. 2001). Binding of cortisol causes dissociation of GR from the stabilizing molecules and allows translocation of the newly formed ligand-receptor complex to the nucleus. This newly formed ligandreceptor complex recognizes and binds to the glucocorticoid response element (GRE) to regulate gene transcription (Bamberger et al. 1996) of gluconeogenic enzymes such as phosphoenolpyruvate carboxykinase (PEPCK) (Nyirenda et al. 1998).

Previous studies have revealed that $11 \beta-H S D 1$ and GR mRNA are present in the fetal sheep liver as early as day 60 of gestation, and increase throughout the rest of pregnancy and postpartum (Yang 1992, Yang et al. 1992, McMillen et al. 2000). There is also evidence that increased cortisol and oestradiol can affect local hepatic glucocorticoid actions by regulating $11 \beta-H S D 1$ and GR expression (Yang et al. 1994, Wang et al. 1997). Increased cortisol has a stimulatory effect on $11 \beta-\mathrm{HSD} 1$, but the data concerning the effects of oestradiol on $11 \beta-H S D 1$ are equivocal. Fetal infusion of glucocorticoid and oestradiol have been found to stimulate $11 \beta-H S D 1$ mRNA expression and enzyme activity (Wang et al. 1997, Sloboda et al. 2001). In contrast, other researchers reported that infusion of dexamethasone (a synthetic glucocorticoid) and oestradiol decreased hepatic $11 \beta$-HSD1 mRNA and reductase activity in the male rat (Jamieson et al. 1999, Nwe et al. 2000). Thus the separate effects of cortisol and oestradiol on hepatic $11 \beta-H S D 1$ and GR in the late-gestation sheep fetus remain unclear. In the present study, we determined the effects of cortisol in the presence or absence of increased oestradiol on hepatic 11ß-HSD1 and GR expression in fetal sheep during late gestation.

\section{Materials and Methods}

\section{Animal preparation}

All animal use and surgical procedures were approved by the University of Toronto Animal Care Committee, in accordance with the guidelines of the Canadian Council for Animal Care. Singleton ewes $(n=20)$ of mixed breed and known gestational ages were used. Gestational age was calculated from the date of insemination (day of mating $=$ day 0 ; term $=147-149$ days of gestation), and the number of fetuses was confirmed by ultrasonography. Surgery was performed with the animal under general anaesthesia as described previously (Manchester et al. 1979). Briefly, polyvinyl catheters were inserted into the maternal femoral artery and vein, fetal carotid artery and fetal jugular vein on days 120-123 of gestation as described elsewhere (Whittle et al. 2000). Stainless steel electrodes were implanted into the myometrium to monitor uterine muscle activity. After 5 days of postoperative recovery, animals entered the experimental procedure.

\section{Experimental procedure}

Beginning on day $125-128$ of gestation, fetuses received a continuous infusion of saline $(3 \mathrm{ml} / \mathrm{h} ; n=10)$ or cortisol $(1.35 \mathrm{mg} / \mathrm{h} ; n=10$; Steraloids Inc., Wilton, NH, USA) in the same volume of infusate. After $24 \mathrm{~h}$ of infusion, five animals in each group received an additional intrafetal infusion of $1.44 \mathrm{mg} / \mathrm{h}$ 4-hydroxyandrostendione (4-OHA; Lentaron, Ciba-Geigy; Basel, Switzerland), a competitive, suicide inhibitor of the $\mathrm{P} 450$ aromatase enzyme (Brodie 1991). Fetal and maternal arterial blood samples were collected at 12-h intervals beginning $24 \mathrm{~h}$ before the start of the infusion procedure and continuing through the infusion period. Blood samples were collected into syringes previously rinsed with heparinized saline, centrifuged at $4{ }^{\circ} \mathrm{C}$, and the plasma stored at $-80{ }^{\circ} \mathrm{C}$ until required for analysis.

Monitoring of uterine activity began $24 \mathrm{~h}$ before the start of the infusion procedure and continued for the infusion period. From preliminary studies (data not shown) 
Table 1 Terminal fetal plasma cortisol and oestradiol concentrations, as published by Holloway et al. (2001) and Whittle et al. (2000) respectively. Values are means \pm S.E.M.

\begin{tabular}{|c|c|c|}
\hline & $\begin{array}{l}\text { Cortisol } \\
\text { (ng/ml) }\end{array}$ & $\begin{array}{l}\text { Oestradiol } \\
(\mathrm{pg} / \mathrm{ml})\end{array}$ \\
\hline Saline & $7 \cdot 2 \pm 2 \cdot 64$ & $37 \pm 14$ \\
\hline Cortisol & $70 \cdot 6 \pm 20 \cdot 34$ & $259 \pm 33$ \\
\hline Saline+4-OHA & $6 \cdot 1 \pm 1 \cdot 83$ & $38 \pm 11$ \\
\hline Cortisol+4-OHA & $56 \cdot 7 \pm 11 \cdot 06$ & $94 \pm 11$ \\
\hline
\end{tabular}

${ }^{*} P<0 \cdot 05$ (two-way ANOVA followed by Tukey's pairwise comparison test).

it was determined that an intrafetal infusion of cortisol for a period of $80 \mathrm{~h}$ was sufficient to induce a pattern of uterine contraction consistent with labour. After completion of an 80-h infusion period, a terminal plasma sample was taken. Infusion of cortisol resulted in increased fetal plasma cortisol and oestradiol concentrations, whereas concurrent infusion of 4-OHA attenuated the increase in fetal plasma oestradiol (Table 1; Holloway et al. 2001, Whittle et al. 2000). Animals were killed with an overdose of Euthanyl (sodium pentobital; MTC Pharmaceuticals, Cambridge, Canada), and fetal liver tissue was collected. Tissues were either fixed in $4 \%$ paraformaldehyde $+0.02 \%$ glutaraldehyde for immunohistochemical analysis, or snap-frozen in liquid nitrogen for subsequent Western blot and enzyme assay analyses.

\section{Immunohistochemical analysis}

Pieces of fetal liver were embedded in paraffin, sectioned at $5 \mu \mathrm{m}$ on a microtome (Histocut, Reichert-Jung, Cambridge Instruments, W. Germany), placed on Superfrost Plus slides (Fisher Scientific, Fair Lawn, NJ, USA) and processed for immunohistochemistry as described elsewhere (Hsu et al. 1981). Briefly, slides were incubated in xylene (VWR Conlab, Mississanga, ON, Canada) to remove the paraffin, and then re-hydrated in a graded series of ethanol dilutions and given a final wash in 0.01 M PBS (pH 7.4; $150 \mathrm{mM} \mathrm{NaCl}, 19 \mathrm{mM} \mathrm{Na}_{2} \mathrm{HPO}_{4}$; $\left.1.5 \mathrm{mM} \mathrm{NaH} \mathrm{PO}_{4}\right)$. Slides were then incubated with rabbit anti-sheep 11ß-HSD1 (1:500 dilution in PBS; antibody from Dr Kaiping Yang, University of Western Ontario), or rabbit anti-human GR (1:100 dilution in PBS; M-20, Santa Cruz Biotechnology Inc., Santa Cruz, CA, USA) polyclonal primary antibody. The avidinbiotin-peroxidase technique (Vectastain ABC Kit; Vector Laboratories, Burlinghame, CA, USA) for immunostaining was utilized with diaminobenzidine (Sigma Chemical Co., St Louis, MO, USA) as the chromagen (Riley et al. 1992). Slides were counterstained with Carazzi's haemotoxylin, dehydrated in a graded series of ethanols, cleared in xylene substitute, and mounted with permount (Fisher
Scientific). As negative control, sections of fetal liver were incubated without the primary antibody.

\section{Assay of 11ß-HSD1 activity}

Reagents and supplies Cortisol $(80 \mathrm{Ci} / \mathrm{mmol})$ was purchased from Du Pont Canada Inc. (Mississauga, ON, Canada). [1,2,6,7- $\left.{ }^{3} \mathrm{H}(N)\right]$ Cortisone was prepared from $\left[1,2,6,7-{ }^{3} \mathrm{H}(\mathrm{N})\right]$ cortisol in our laboratory as described previously (Alfaidy et al. 2001). Non-radioactive steroids were obtained from Steraloids Inc. Cofactors NADPH and NADP were purchased from Sigma Chemical Co. Polyester-backed thin-layer chromatography plates were obtained from Fisher Scientific (Unionville, ON, Canada). All solvents used were OmniSolv grade from BDH Inc. (Toronto, ON, Canada).

Hepatocyte microsomal preparation Fetal liver tissues were homogenized in buffer $(10 \%$ glycerol, $300 \mathrm{mM}$ $\mathrm{NaCl}, 1 \mathrm{mM}$ EDTA, and 0.02 M Tris-HCl; pH 7.4). For microsomal preparation, tissue homogenate from each liver sample was centrifuged at $4{ }^{\circ} \mathrm{C}$ at $790 \boldsymbol{g}$ for $10 \mathrm{~min}$ and the supernatant then centrifuged at $4{ }^{\circ} \mathrm{C}$ at $25000 \mathrm{~g}$ for $40 \mathrm{~min}$. This supernatant was centrifuged at $4{ }^{\circ} \mathrm{C}$ at $110000 \mathrm{~g}$ for $60 \mathrm{~min}$ and the pellet containing the microsomal fraction was resuspended in 200-300 $\mu$ l11 $\beta$-HSD1 homogenization buffer and stored until required for protein concentration determination using the Bio-Rad protein assay kit with BSA (Bio-Rad Laboratories, Inc., Richmond, CA, USA) as standard and protein absorbance measured at $595 \mathrm{~nm}$ (Bradford 1976).

Assay of 11ß-HSD1 reductase and dehydrogenase activities $11 \beta-\mathrm{HSD} 1$ reductase activity was assessed by measuring the rate of conversion of $\left[{ }^{3} \mathrm{H}\right]$ cortisone to $\left[{ }^{3} \mathrm{H}\right]$ cortisol. In preliminary experiments, incubations were conducted for various times between 0 and $120 \mathrm{~min}$ to ensure measurement of levels of enzyme activity within the linear range; the optimal incubation period was determined to be $60 \mathrm{~min}$. To assess $11 \beta$-reductase activity, microsomal fractions (100 $\mu \mathrm{g}$ microsomal protein) were incubated in $250 \mu \mathrm{l}$ buffer containing cortisone $\left(10^{-6} \mathrm{M}\right)$ and $\left.{ }^{3} \mathrm{H}\right]$ cortisone as tracer, in the presence of NADPH $\left(10^{-3} \mathrm{M}\right)$ at $37^{\circ} \mathrm{C}$ for $60 \mathrm{~min}$. The dehydrogenase activity was determined by incubating $200 \mu \mathrm{g} /$ $250 \mu \mathrm{l}$ liver microsomal fraction with cortisol $\left(10^{-6} \mathrm{M}\right)$, and $\left[{ }^{3} \mathrm{H}\right]$ cortisol as tracer, in the presence of NADP $\left(10^{-3} \mathrm{M}\right)$ at $37^{\circ} \mathrm{C}$ for $60 \mathrm{~min}$. All reactions were stopped by immediate transfer of the tubes to ice and the addition of ethyl acetate $(750 \mu \mathrm{l}$ in a final volume of $1 \mathrm{ml}$; Sigma). The steroids were extracted using ethyl acetate, and separated on silicon-coated thin-layer chromatography plates (Fisher Scientific) using chloroform:ethanol (95:5 vol:vol). Radioactivity was counted using a $\beta$-counter. $11 \beta-H S D 1$ activity was expressed as pmol cortisol or cortisone formed/ $\mu \mathrm{g}$ microsomal protein per min. 

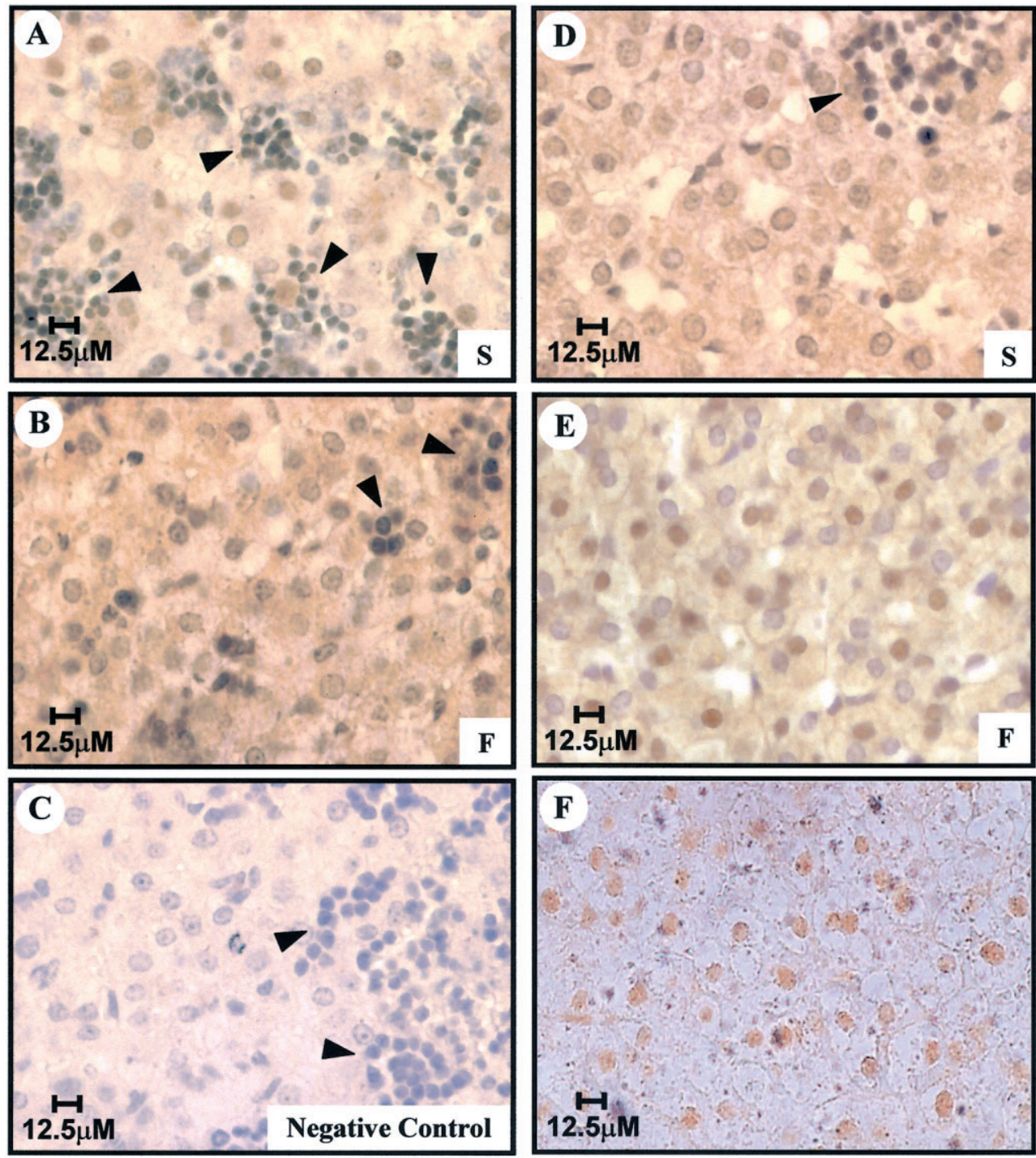

Figure 1 Immunohistochemical localization of ir11 -HSD1 $(A-B)$ and GR proteins $(D-F)$ in the liver of ovine fetuses infused with $(A, D)$ saline $(S)$, and $(b, e)$ cortisol $(F)$. (C) Negative control. (A-E) Slides are counterstained with Carazzi's haemotoxylin; (F) slide not counterstained. Arrowheads indicate haematopoietic cell clusters.

\section{Western blot analysis}

Frozen liver samples were homogenized on ice for $1 \mathrm{~min}$ in RIPA lysis buffer [50 $\mathrm{nM}$ Tris- $\mathrm{HCl}(\mathrm{pH} 7 \cdot 5)$, $150 \mathrm{mM} \mathrm{NaCl}, 1 \%$ (wt/vol) sodium deoxycholate, $0 \cdot 1 \%$ SDS, $100 \mathrm{mM}$ sodium orthovanadate (Sigma), 1\% (vol/ vol) Triton X-100 (Fisher Scientific) and Complete MiniEDTA-free protease inhibitors (Roche Molecular Biochemicals; Dorval, Canada)]. Homogenates were centrifuged at $4{ }^{\circ} \mathrm{C}$ at $15000 \mathrm{~g}$ for $15 \mathrm{~min}$, and supernatants were collected. Protein concentrations were determined by the Bradford assay (Bradford 1976).

Polyacrylamide gels were prepared (stacking gel 4\%; separating gel $12 \%$ for $11 \beta$-HSD1, $8 \%$ for GR). Proteins
(70 $\mu \mathrm{g} /$ well) were separated by PAGE, and then transferred electrophoretically to a $0 \cdot 45-\mu \mathrm{m}$ pore nitrocellulose membrane (Bio-Rad Laboratories, Inc.). Transfer was confirmed by protein visualization with Ponceau $\mathrm{S}$ (Sigma). Blots were washed with PBS-T $[150 \mathrm{mM} \mathrm{NaCl}$, $10 \mathrm{mM} \quad \mathrm{Na}_{2} \mathrm{HPO}_{4}, \quad 1.5 \mathrm{mM} \quad \mathrm{NaH}_{2} \mathrm{PO}_{4}$, and $0 \cdot 1 \%$ Tween-20 (Sigma); pH 7.5] and incubated overnight with blocking solution (5\% skim milk powder in PBS-T). Subsequently, blots were incubated with primary antibody for rabbit anti-sheep 11ß-HSD1 (1:1000 dilution in blocking solution), or anti-human GR (1:250 dilution in blocking solution; Santa Cruz Biotechnology, Inc.) for $1 \mathrm{~h}$. For negative controls, the membranes were incubated 
without primary antibody. GR antibody was also preabsorbed with a corresponding peptide sequence against which the antibody had been raised $(10 \mu \mathrm{g}$ blocking peptide per $1 \mu \mathrm{g}$ antibody per $\mathrm{ml} 5 \%$ blocking solution; Affinity Bioreagents Inc., Neshanic Station, NJ, USA) overnight at $4{ }^{\circ} \mathrm{C}$ (shaking) before being used for Western blot analysis. All blots were then rinsed six times for 5 min each with PBS-T and incubated with secondary rabbit antiserum conjugated with horseradish peroxidase (1:1000 dilution in blocking solution; Amersham Pharmacia Biotech) for $1 \mathrm{~h}$. Blots were washed six times, 5 min each, and the antibody-antigen complex was detected using the Amersham Pharmacia Biotech enhanced chemiluminescence detection system. Blots were exposed to X-ray film (Eastman Kodak Co.) for visualization. The intensity of the protein signal was quantified using computerized image analysis software (Image Research Inc., laser scanner from Molecular Dynamics, Inc.; ImageQuant software) and expressed as relative optical density (ROD). Protein bands were digitized and the mean pixel density for each band was analysed to obtain ROD units for each protein. In order to compare measurements between different blots, a control liver sample was included in each gel.

\section{Statistical analysis}

Data were analysed by two-way analysis of variance (ANOVA). When significance was reached, data were compared further using Tukey's pairwise comparison test and significance was set at $P<0 \cdot 05$. Results are presented as the mean $\mathrm{ROD} \pm$ S.E.M. of averages for $n=5$ animals per treatment group.

\section{Results}

\section{Localization of $11 \beta$-HSD1 protein}

Immunohistochemical analysis revealed localization of the immunoreactive (ir) $11 \beta-H S D 1$ protein to the fetal hepatocytes of all treatment groups (Fig. 1A,B). In some tissue sections, hepatic ir11 $\beta-H S D 1$ protein was observed in a radiating pattern around the central and portal veins in addition to some bile ducts, although this was not a consistent finding (data not shown). Liver sections of fetuses infused with saline or saline +4-OHA contained clusters of haematopoeitic cells that were large in number and cluster size (Fig. 1A,D; arrowhead); the number and size of clusters decreased markedly in liver sections of animals infused with cortisol (arrowheads in Fig. 1B,E;). The negative control, obtained by incubating the sections without primary antibody, revealed no immunoreactivity in the tissues (Fig. 1C).

\section{Level of expression of $11 \beta$-HSD1 protein}

Western blot analysis revealed bands with molecular weights of 32, 34 and $68 \mathrm{kDa}$ in homogenates of fetal liver from all groups of animals (Fig. 2A). Expression of the $32 \mathrm{kDa}$ molecular weight band did not change across the treatment groups (Fig. 2B). In comparison, the $34 \mathrm{kDa}$ form increased with the infusion of cortisol in the presence or absence of 4-OHA, although this was only significant in the absence of increased oestradiol production (Fig. 2C). The $68 \mathrm{kDa}$ band had a similar pattern of change as the $34 \mathrm{kDa}$ band, although the mean values were not significantly different from each other (Fig. 2D).

\section{$11 \beta$-HSD1 reductase and dehydrogenase activities}

Enzyme activity assay indicated bidirectional $11 \beta-H S D 1$ isoenzyme activity in the fetal liver (Fig. 3). However, $11 \beta$-reductase activities were significantly greater than dehydrogenase activities in all groups (Fig. 3). Infusion of cortisol, with or without concurrent administration of 4-OHA, increased the rate of conversion (expressed as $\mathrm{pmol} / \mu \mathrm{g}$ microsomal protein per min), and this increase was significant in the absence of increased oestradiol concentrations.

\section{Localization of GR protein}

Immunoreactive irGR was localized to the cytosol and nuclei of fetal hepatocytes (Fig. 1D-F). Tissue sections were either counterstained with Carazzi's haematoxylin to visualize the nuclei (Fig. 1D,E) or left without counterstain (Fig. 1F) to visualize nuclear irGR localization. Infusion of cortisol (Fig. 1E) appeared to increase both cytosolic and nuclear expression compared with control (Fig. 1D).

\section{Level of expression of GR protein}

Western blot analysis revealed a major band of approximately $95 \mathrm{kDa}$, as well as additional bands of 45 and $57 \mathrm{kDa}$ molecular weights (Fig. 4A). The intensity of the $95 \mathrm{kDa}$ (GR protein) band increased significantly $(P<0.05)$ after infusion of cortisol in the presence of 4-OHA (Fig. 4B). The double $45 \mathrm{kDa}$ and $57 \mathrm{kDa}$ molecular weight bands were analysed together; the RODs obtained indicated a similar pattern of change as the $95 \mathrm{kDa}$ band. Negative control, performed either by substituting the primary antibody with pre-immune rabbit serum (data not shown) or by preabsorbing the primary antibody with GR blocking peptide (Fig. 4A), eliminated or markedly reduced band intensity.

\section{Discussion}

We demonstrated that both $11 \beta-$ HSD 1 and GR proteins are localized to fetal sheep hepatocytes in late gestation and that expression of both proteins was increased in animals infused with cortisol, especially in the absence of increased 
A)
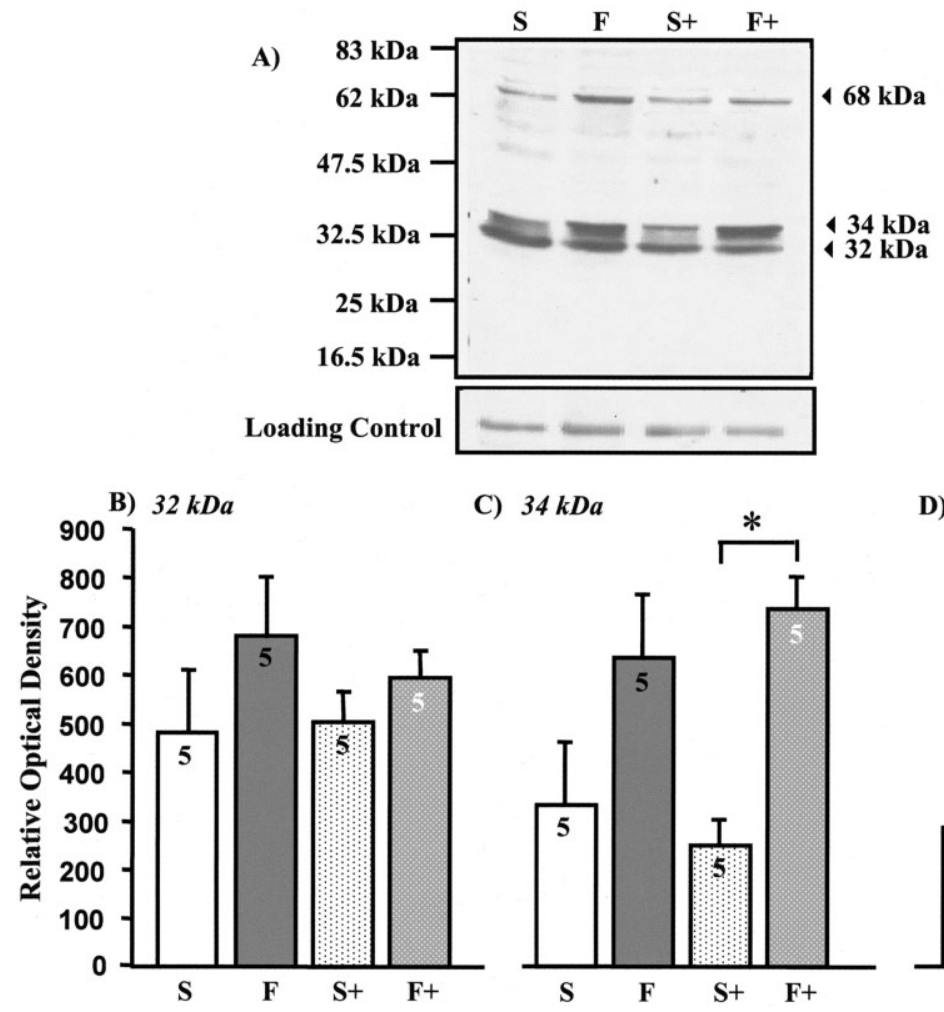

C) $34 \mathrm{kDa}$

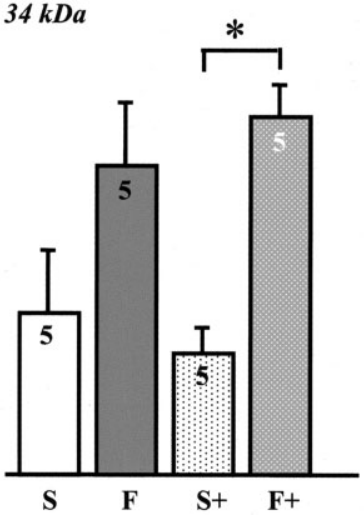

D) $68 \mathrm{kDa}$

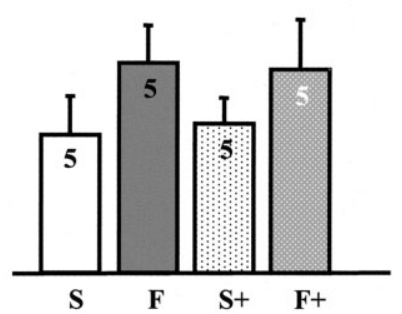

Figure 2 Western blot analysis of $11 \beta-H S D 1$ protein expression in fetal liver after infusion of cortisol (F) in the presence or absence of 4-OHA, a P450 aromatase inhibitor. (A) Representative Western blot autoradiographic film; (B-D) mean RODs of hepatic $11 \beta$-HSD1. Levels of expression of (B) $32 \mathrm{kDa}$, (C) $34 \mathrm{kDa}$ and (D) $68 \mathrm{kDa}$ proteins after treatment with saline (S), cortisol (F), saline+4-OHA (S+), or cortisol + 4-OHA $(\mathrm{F}+$ ). Loading control, blot incubated with $\mathrm{S}$ Ponceau. Values are mean RODs \pm S.E.M. ${ }^{*} P<0 \cdot 05$, two-way ANOVA followed by Tukey's pairwise comparison test.

oestradiol concentrations. Therefore, we suggest that the prepartum increase in fetal cortisol not only increases responsiveness to glucocorticoids by increasing GR, but also increases the ability of the liver to generate cortisol locally from cortisone, through increased $11 \beta$ HSD1 reductase activity. These effects were diminished in the presence of 4-OHA, suggesting that the prepartum increase in oestrogen may attenuate these effects of cortisol.

$11 \beta-H S D 1$ was generally present in a radiating pattern around the central veins, portal veins and bile ducts. Ricketts et al. (1998b) have previously reported a similar radiating pattern of $11 \beta-H S D 1$ localization in the human liver, with maximal expression around the central veins. Brereton et al. (2001) recently reported the isoenzyme to be concentrated around the central vein, while being absent from the vicinity of bile ducts of rat liver. In addition, our findings of cellular and nuclear localization for ir11 $\beta-H S D 1$ protein in hepatocytes are consistent with recent findings of its localization to the endoplasmic reticulum and the nuclear membrane (Brereton et al. 2001, Filling et al. 2001).
Western blot analysis revealed double bands of 32 and $34 \mathrm{kDa}$ molecular weight, possibly corresponding to different glycosylated forms of $11 \beta-H S D 1$ proteins as previously described (Blum et al. 2000). Expression of the $34 \mathrm{kDa}$ glycosylated form of the enzyme is believed to reflect a more mature, physiologically active form, whereas the $32 \mathrm{kDa}$ non-glycosylated form is proposed to be immature and to require further processing before being rendered functionally active. However, Blum et al. (2000) have reported that human $11 \beta-H S D 1$ is enzymatically active regardless of its degree of glycosylation. Expression of the immature $32 \mathrm{kDa}$ form remained relatively constant, with increased cortisol in the presence or absence of increased oestradiol concentrations. However, cortisol stimulated the mature $34 \mathrm{kDa}$ form; this response was further enhanced in the absence of increased oestradiol concentrations. Similar stimulatory effects were observed for $11 \beta-H S D 1$ enzyme activity. We also detected an additional protein of $68 \mathrm{kDa}$ molecular weight, which may correspond to a dimeric form of the enzyme. Changes in the $68 \mathrm{kDa}$ molecular weight form followed a similar pattern of change as the $34 \mathrm{kDa}$ band, further supporting 

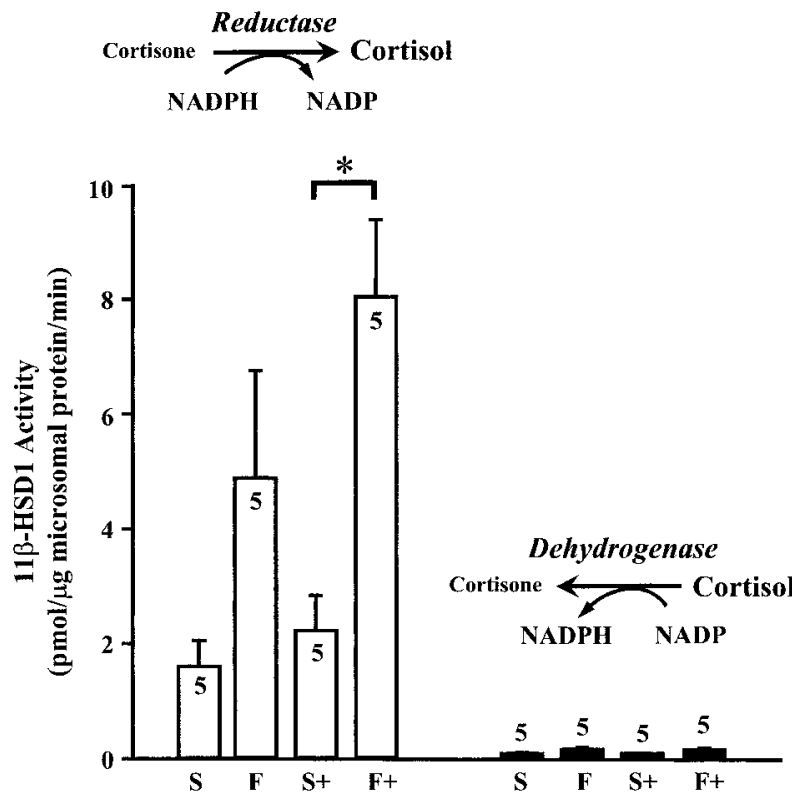

Figure $3 \beta$-HSD1 reductase $(\square)$ and dehydrogenase $(\square)$ activities in the fetal liver after intrafetal infusion of saline $(S)$, cortisol $(F)$, saline + 4-OHA $(\mathrm{S}+)$, or cortisol+4-OHA $(\mathrm{F}+)$. Values are mean \pm S.E.M. ${ }^{*} P<0 \cdot 05$, two-way ANOVA followed by Tukey's pairwise comparison test.

a role for cortisol and oestradiol in the post-translational regulation of hepatic $11 \beta-H S D 1$. The stimulatory effects of cortisol on hepatic expression of $11 \beta-H S D 1$ protein and enzyme activity are consistent with previous findings of changes in mRNA and enzyme activity. Increased hepatic $11 \beta-H S D 1 \mathrm{mRNA}$ and enzyme activity during gestation that correlate with increased systemic cortisol concentrations in the late-gestation sheep fetus have been reported (Yang et al. 1992, Langlois et al. 1995, McMillen et al. 2000). Administration of cortisol or betamethasone has been shown to stimulate hepatic expression of $11 \beta-$ HSD1 mRNA and protein, and enzyme activity, in late-gestation fetal sheep liver (Yang et al. 1994, Sloboda et al. 2001). Dexamethasone has also been shown to stimulate $11 \beta-$ HSD1 activity in primary culture of rat hepatocytes (Liu et al. 1996). In addition, it has been shown that expression of $11 \beta$-HSD1 is increased after occlusion of the ductus venosus and concomitant increase in plasma cortisol concentrations (Tchirikov et al. 2001).

Our finding of an apparent attenuation of stimulated $11 \beta-H S D 1$ by oestrogen is consistent with previous evidence for the inhibition of hepatic 11 $\beta-H S D 1$ mRNA and activity in the fetus by oestradiol (Low et al. 1993, Seckl \& Walker 2001). In the rat, males have significantly greater hepatic expression of $11 \beta$-HSD1 mRNA than females, and the levels in males can be suppressed by the administration of oestradiol (Low et al. 1994, Albiston et al. 1995). These inhibitory effects of oestradiol on $11 \beta-H S D 1$ may be mediated indirectly by growth hormone (GH).
A)

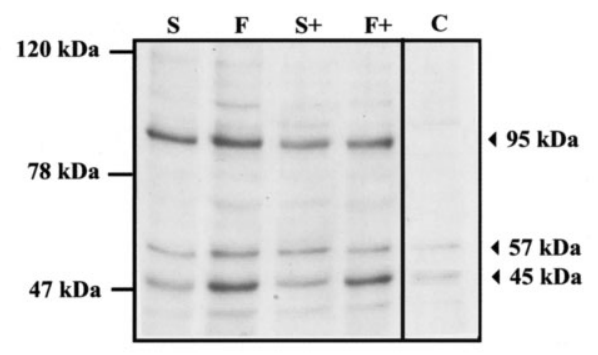

B) $95 \mathrm{kDa}$

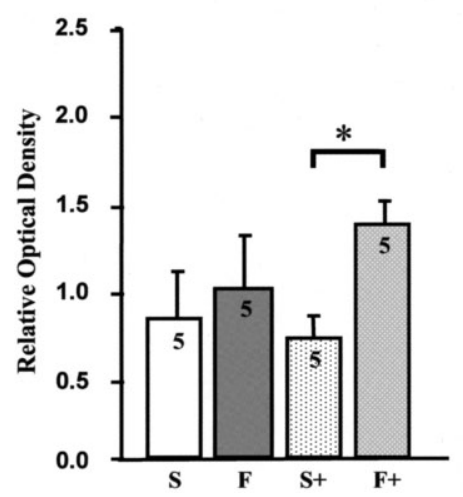

C) $45-57 \mathrm{kDa}$

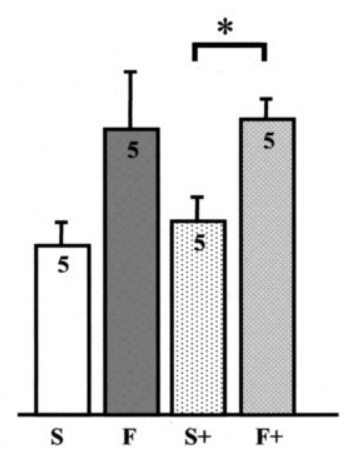

Figure 4 Western blot analysis of expression of GR protein in ovine fetal liver after fetal infusion of cortisol in the presence or absence of 4-OHA, a P450 aromatase inhibitor. (A) Representative Western blot autoradiographic film; $(B, C)$ mean RODs of hepatic GR. Levels of expression of (B) $95 \mathrm{kDa}$ and (C) double 45-57 kDa protein after treatment with saline $(\mathrm{S})$, cortisol $(\mathrm{F})$, saline+4-OHA $(\mathrm{S}+)$, and cortisol+4-OHA $(\mathrm{F}+)$. Values are mean RODs \pm S.E.M. ${ }^{*} P<0 \cdot 05$, two-way ANOVA followed by Tukey's pairwise comparison test.

Low et al. (1994) further demonstrated that continuous administration of $\mathrm{GH}$ to male rats (mimicking the pattern of secretion of GH in the female) suppressed 11 $\beta-\mathrm{HSD} 1$ activity, whereas pulsatile administration of GH (mimicking the pattern of secretion of GH in the male) had no effect (Stewart et al. 2001). Similarly, GH has been shown to inhibit $11 \beta$-HSD1 activity in primary cultures of rat hepatocytes (Liu et al. 1996). However, Wang et al. (1997) have reported increased hepatic $11 \beta-H S D 1$ mRNA after the administration of oestrogen to late-gestation fetal sheep, suggesting that there may be differences in response depending upon the duration and magnitude of the oestrogen administration. It is also possible that, in the present study, the P450 aromatase inhibitor affected $11 \beta$ HSD1 directly, or that its mechanism of action results in accumulation of C19 steroids - oestrogen precursors that influence $11 \beta-H S D 1$. The simplest explanation for the apparent discrepancy between the present results and those of Wang et al. (1997), and for the paradox of potentially opposing effects of cortisol and oestrogen in the fetus at term, may lie in the different experimental models 
used in these studies, or in effects of 4-OHA that are additional to decreasing stimulated oestrogen concentrations. In addition, examination of the regulation of $11 \beta-H S D 1$ by oestradiol and GH is plausible in fetal sheep after intrafetal administration of GH (Bauer et al. 2000).

Assessment of $11 \beta-H S D 1$ enzyme activity revealed markedly greater $11 \beta$-reductase activity (cortisone to cortisol) compared with dehydrogenase activity (cortisol to cortisone). This is compatible with previous findings (Yang et al. 1994) and reinforces the concept that the liver is a potential extra-adrenal source of fetal cortisol during term gestation. Cortisol stimulated reductase activity, and thus acts in a positive feed-forward mechanism to enhance local hepatic production of cortisol. Although increased oestradiol appeared to inhibit local conversion of cortisone to cortisol, these effects were minimal and only apparent in the presence of increased cortisol.

The GR, expressed highly in the fetal liver, is another important mediator of the local action of hepatic cortisol. In the inactive state, ligand-free GR monomer is stabilized in the cytoplasm by binding to a complex of molecules, including heat shock proteins (hsp70, hsp90) and immunophilin FK binding proteins (i.e. FKBP52 and FKBP51 in rodents) (Bamberger et al. 1996). Upon binding of the ligand, GR monomers are believed to dissociate from the stabilizing complex. Only the newly formed receptorligand complexes are believed to dimerize and translocate to the nucleus, where they recognize and bind to the GRE and initiate specific gene transcription.

We found GR to be localized to the cytosol and nuclei of fetal hepatocytes. Increased GR immunoreactivity in the cytoplasm and nuclei after infusion of cortisol suggests increased synthesis, in addition to activation and nuclear translocation of the receptor. Using Western blot analysis, we found bands of 45, 57 and $95 \mathrm{kDa}$ molecular weight in the fetal liver. The smaller 45 and $57 \mathrm{kDa}$ bands may reflect receptor fragments or metabolites. Saoud \& Wood (1996) have also previously reported a $45 \mathrm{kDa}$ band in sheep pituitary and hypothalamus. The presence of these additional bands suggests possible tissue-specific pathways of post-translational GR metabolism, but their functional significance is unclear. The larger $95 \mathrm{kDa}$ band reflects the full GR protein. Intrafetal infusion of cortisol had an overall stimulatory effect on GR, although this was significant only in the absence of increased oestradiol. These findings contrast with the classical negative feedback regulatory mechanism seen in adults and suggest altered regulation of the steroid receptor in the fetus compared with the adult (Bamberger et al. 1996). Infusions of cortisol and dexamethasone to the fetus have previously been shown to stimulate GR mRNA in the rat liver (Cleasby et al. 2001). Evidence of increased placental and pituitary expression of GR mRNA and protein after the infusion of cortisol (Holloway et al. 2001, Whittle et al. 2001) suggests a similar pattern of regulation in late gestation trophoblast, in addition to fetal tissue. Previous findings of a correlation between the degree of receptor phosphorylation and functional significance provide evidence for a posttranslational mechanism of receptor processing in mediating the action of cortisol in the fetal liver (Orti et al. 1992, Bamberger et al. 1996).

Prenatal exposure to glucocorticoids in rats has been shown to induce hyperglycaemia in adult offspring, and both altered lipid metabolism and increased insulin sensitivity in the fetus (Lindsay et al. 1996, Nyirenda et al. 2001). Glucocorticoids have been shown to oppose the actions of insulin in the liver by upregulating expression of the rate-limiting enzyme PEPCK (Low et al. 1994). Oestradiol, only in the presence of glucocorticoids, also downregulates expression of PEPCK (Jamieson et al. 1999). Morton et al. (2001) and others have shown that $11 \beta-H S D 1-n u l l$ mice have increased hepatic insulin sensitivity, and increased glycaemic control for similar insulin concentrations. Increased hepatic expression of $11 \beta-H S D 1$ and reductase activity, and a subsequent increase in local hepatic cortisol production, may result in induction of glucocorticoid-specific genes in the liver. Our findings also suggest that these effects would be propagated further by increased local hepatic expression of GR. In light of these results, we speculate that fetal sheep exposed to increased cortisol might show a predisposition to hepatic changes leading to hyperglycaemia, insulin resistance and later programming of inappropriate glycaemic control (Dodic et al. 1999).

In conclusion, we have demonstrated steroid-mediated regulation of the expression of $11 \beta-H S D 1$ and GR in fetal sheep liver. The expression of $11 \beta-H S D 1$ protein allows for local regulation of physiologically active glucocorticoids. Upregulation of GR in the presence of cortisol infusion is consistent with increased hepatic responsiveness to glucocorticoids in late gestation. The apparent attenuation by oestradiol of cortisol-induced expression of $11 \beta$ HSD1 and GR protein may reflect a balance of these steroid hormone actions on local glucocorticoid regulation during normal pregnancy. We speculate that inappropriate upregulation of these proteins in response to precocious changes in fetal plasma cortisol may contribute to mechanisms by which fetal hepatic function is altered in a way that affects postnatal glucose homeostasis.

\section{Acknowledgement}

This research was funded by Canadian Institutes of Health Research (CIHR), Institute of Human Development, Child and Youth Health, Grant No. MOP-14097.

\section{References}

Albiston AL, Smith RE \& Krozowski ZS 1995 Sex- and tissue-specific regulation of $11 \beta$-hydroxysteroid dehydrogenase mRNA. Molecular and Cellular Endocrinology 109 183-188. 
Alfaidy N, Xiong ZG, Myatt L, Lye SJ, MacDonald JF \& Challis JRG 2001 Prostaglandin F2 $\alpha$ potentiates cortisol production by stimulating $11 \beta$-hydroxysteroid dehydrogenase 1 : a novel feedback loop that may contribute to human labor. Journal of Clinical Endocrinology and Metabolism 86 5585-5592.

Bamberger CM, Schulte HM \& Chrousos GP 1996 Molecular determinants of glucocorticoid receptor function and tissue sensitivity to glucocorticoids. Endocrine Reviews 17 245-261.

Bassett JM \& Thorburn GD 1969 Fetal plasma corticosteroids and the initiation of parturition in sheep. Journal of Endocrinology 44 285-286.

Bauer MK, Harding JE, Breier BH \& Gluckman PD 2000 Exogenous $\mathrm{GH}$ infusion to late-gestational fetal sheep does not alter fetal growth and metabolism. Journal of Endocrinology 166 591-597.

Blum A, Martin J \& Maser E 2000 Human 11ß-hydroxysteroid dehydrogenase type 1 is enzymatically active in its nonglycosylated form. Biochemical and Biophysical Research Communications $\mathbf{2 7 6}$ 428-434.

Bradford MM 1976 A rapid and sensitive method for the quantification of microgram quantities of protein utilizing the principle of protein-dye binding. Annals of Biochemistry 72 248-254.

Brereton PS, Van Driel RR, Suhaimi FBJ, Koyama K, Dilley R \& Krozowski Z 2001 Light and electron microscopy localization of the $11 \beta$-hydroxysteroid dehydrogenase type 1 enzyme in the rat. Endocrinology 142 1644-1651.

Brodie A 1991 Aromatase and its inhibitors - an overview. Journal of Steroid Biochemistry and Molecular Biology 40 255-261.

Brown RW, Chapman KE, Murad P, Edwards CRW \& Seckl JR 1996 Purification of $11 \beta$-hydroxysteroid dehydrogenase type 2 from human placenta utilizing a novel affinity labeling technique. Biochemical Journal 313 997-1005.

Bujalska IJ, Kumar S \& Stewart PM 1997 Does central obesity reflect 'Cushing's disease of the omentum'? Lancet 349 1210-1213.

Challis JRG \& Brooks AN 1989 Maturation and activation of the hypothalamic-pituitary-adrenal function in fetal sheep. Endocrine Reviews 10 182-204.

Cleasby CME, Nyirenda MJ, Walker BR \& Seckl JR 2001 Programming of the glucocorticoid receptor in insulin target tissues and its modulation by metformin and rosiglitazone. Proceedings of the Endocrine Society, 83rd Meeting, Denver, CO, USA. Abstract P1-343.

Dodic M, Peers A, Coghlan JP \& Wintour M 1999 Can excess glucocorticoid, in utero, predispose to cardiovascular and metabolic disease in middle age? Trends in Endocrinology and Metabolism 10 86-91.

Filling C, Wu X, Shafqat N, Hult M, Martonsson E, Shafqat J \& Opperman UCT 2001 Subcellular targeting analysis of SDR-type hydroxysteroid dehydrogenases. Molecular and Cellular Endocrinology 171 99-101.

Fowden AL, Mundy L \& Silver M 1998 Developmental regulation of gluconeogenesis in the sheep fetus during late gestation. Journal of Physiology 508 937-947.

Galigniana MD, Radanyi C, Renoir JM, Housley PR \& Pratt WB 2001 Evidence that the peptidylprolyl isomerase domain of the hsp90-binding immunophilin FKBP52 is involved in both dynein interaction and glucocorticoid receptor movement to the nucleus. Journal of Biological Chemistry 276 14884-14889.

Holloway AC, Whittle WL \& Challis JRG 2001 Effects of cortisol and estradiol on pituitary expression of proopiomelanocortin, prohormone convertase-1, prohormone convertase-2, and glucocorticoid receptor mRNA in fetal sheep. Endocrine 14 343-348.

Hsu S, Raine L \& Fanger H 1981 A comparative study of the peroxidase-antiperoxidase method and an avidin-biotin complex method for studying polypeptide hormones with radioimmunoassay antibodies. American Journal of Clinical Pathology 75 734-738.
Hundertmark S, Buhler H, Ragosch V, Dinkelborg L, Arabin B \& Weitzel HK 1995 Correlation of surfactant phosphatidylcholine synthesis and 11ß-hydroxysteroid dehydrogenase in the fetal lung. Endocrinology 136 2573-2578.

Jamieson PM, Chapman KE, Edwards CRW \& Seckl JR 1995 $11 \beta$-Hydroxysteroid dehydrogenase is an exclusive $11 \beta$-reductase in primary cultures of rat hepatocytes: effects of physiochemical and hormonal manipulations. Endocrinology 136 4754-4761.

Jamieson PM, Nyirenda MJ, Walker BR, Chapman KE \& Seckl JR 1999 Interactions between estradiol and glucocorticoid regulatory effects on liver-specific glucocorticoid-inducible genes: possible evidence for a role of hepatic $11 \beta$-hydroxysteroid dehydrogenase type 1. Journal of Endocrinology $160103-109$.

Jamieson PM, Walker BR, Chapman KE, Andrew R, Rossiter S \& Seckl JR $200011 \beta$-Hydroxysteroid dehydrogenase type 1 is a predominant $11 \beta$-reductase in the intact perfused rat liver. Journal of Endocrinology 165 685-692.

Kim EK, Wood CE \& Keller-Wood M 1995 Characterization of $11 \beta$-hydroxysteroid dehydrogenase activity in fetal and adult ovine tissues. Reproduction, Fertility and Development 7 377-383.

Langlois DA, Matthews SG, Yu M \& Yang K 1995 Differential expression of $11 \beta$-hydroxysteroid dehydrogenase 1 and 2 in the developing ovine fetal liver and kidney. Journal of Endocrinology 147 405-411.

Liggins GC 1976 Adrenocortical-related maturational events in the fetus. American Journal of Obstetrics and Gynecology 126 931-939.

Lindsay RS, Lindsay RM, Waddell BJ \& Seckl JR 1996 Prenatal glucocorticoid exposure leads to hyperglycemia in the rat: studies with $11 \beta$-hydroxysteroid dehydrogenase inhibitor carbenoxolone. Diabetologia 39 1299-1305.

Liu YJ, Nakagawa Y, Nasuda K, Saegusa H \& Igarashi Y 1996 Effect of growth hormone, insulin and dexamethasone on $11 \beta$-hydroxysteroid dehydrogenase activity on a primary culture of rat hepatocytes. Life Science 59 227-234.

Low SC , Assaad SN, Rajan V, Chapman KE, Edwards CRW \& Seckl JR 1993 Regulation of 11 $\beta$-hydroxysteroid dehydrogenase by sex steroids in vivo: further evidence for the existence of a second dehydrogenase in rat kidney. Journal of Endocrinology 139 $27-35$.

Low SC, Chapman KE, Edwards CRW, Wells T, Robinson ICAF \& Seckl JR 1994 Sexual dimorphism of hepatic $11 \beta$-hydroxysteroid dehydrogenase in the rat: the role of growth hormone patterns. Journal of Endocrinology 143 541-548.

McMillen IC, Warnes KE, Adams MB, Robinson JS, Owens JA \& Coulter CL 2000 Impact of restriction of placental and fetal growth on expression of $11 \beta$-hydroxysteroid dehydrogenase type 1 and type 2 messenger ribonucleic acid in the liver, kidney, and adrenal of the sheep fetus. Endocrinology 141 539-543.

Manchester EL, Challis JRG, MacLennan EA, Patrick JE \& Workewych JV 1979 A chronic fetal lamb preparation. Proceedings of the Canadian Association for Laboratory Animal Science 17 29-39.

Monder C \& White PC 1993 11ß-Hydroxysteroid dehydrogenase. Vitamins and Hormones 47 187-271.

Morton NM, Holmes MC, Fievet C, Staels B, Tailleux A, Mullins JJ \& Seckl JR 2001 Improved lipid and lipoprotein profile, hepatic insulin sensitivity, and glucose tolerance in $11 \beta$-hydroxysteroid dehydrogenase type 1 null mice. Journal of Biology and Chemistry 276 41293-41300.

Nwe KH, Hamid A, Morat PB \& Khalid BAK 2000 Differential regulation of the oxidative $11 \beta$-hydroxysteoid dehydrogenase activity in testes and liver. Steroids 65 40-45.

Nyirenda MJ, Lindsay RS, Kenyon CJ, Burchell A \& Seckl JR 1998 Glucocorticoid exposure in late gestation permanently programs rat hepatic phosphoenolpyruvate carboxykinase and glucocorticoid receptor expression and causes glucose intolerance in adult offspring. Journal of Clinical Investigation 101 2174-2181. 
Nyirenda MJ, Welberg LAM \& Seckl JR 2001 Programming hyperglycemia in the rat through prenatal exposure to glucocorticoids - fetal effect or maternal influence? Journal of Endocrinology 170 653-660.

Orti E, Bodwell JE \& Munck A 1992 Phosphorylation of steroid hormone receptors. Endocrine Review 13 105-128.

Raddatz D, Henneken M, Armburst T \& Ramadori G 1996 Subcellular distribution of glucocorticoid receptor in cultured rat and human liver-derived cells and cell lines: influence of dexamethasone. Hepatology 24 928-933.

Rajan VI, Edwards CRW \& Seckl JR 1996 11ß-Hydroxysteroid dehydrogenase in cultured hippocampal cells reactivates inert 11-dehydrocorticosterone, potentiating neurotoxicity. Journal of Neuroscience 16 65-70.

Rask E, Olsson T, Soderberg S, Andrew R, Livingston DE, Johnson O \& Walker BR 2001 Tissue-specific disregulation of cortisol metabolism in human obesity. Journal of Clinical Endocrinology and Metabolism 86 1418-1421.

Ricketts ML, Sheosmith KE, Hewison M, Strain A, Eggo MC \& Stewart PM 1998a Regulation of $11 \beta-H S D ~ 1$ in primary cultures of rat and human hepatocytes. Journal of Endocrinology 156 159-168.

Ricketts ML, Verhag JM, Bujalska I, Howie AJ, Rainey WE \& Stewart PM 1998b Immunohistochemical localization of type 1 $11 \beta$-hydroxysteroid dehydrogenase in human tissues. Journal of Clinical Endocrinology and Metabolism 83 1325-1335.

Riley SC, Greer IA, Schembri LA \& Challis JR G 1992 Dexamethasone inhibits basal and stimulated prostaglandin $\mathrm{E}_{2}$ output from human placental cells by inhibition of prostaglandin $\mathrm{H}$ synthase. Gynecologic and Obstetric Investigation 33 85-89.

Rusvai E \& Naray-Fejes-Toth A 1993 A new isoform of $11 \beta$-hydroxysteroid dehydrogenase in aldosterone target cells. Journal of Biological Chemistry 268 10717-10720.

Saond CJ \& Wood CE 1996 Developmental changes and molecular weight of immunoreactive glucocorticoid receptor protein in the ovine fetal hypothalamus and pituitary. Biochemical and Biophysical Research Communications 229 916-921.

Seckl JR \& Walker BR 2001 Minireview: 11ß-hydroxysteroid dehydrogenase type 1 - a tissue-specific amplifier of glucocorticoid action. Endocrinology 142 1371-1376.

Silver M 1990 Prenatal maturation, the timing of birth and how it is regulated in domestic animals. Experimental Physiology 75 285-307.

Sloboda DM, Newnham JP \& Challis JRG 2001 Prenatal betamethasone administration alters fetal hepatic $11 \beta$-hydroxysteroid dehydrogenase type 1 (11 $\beta$-HSD1) and corticosteroid binding globulin (CBG) levels. Journal of the Society for Gynecologic Investigations 8 (Suppl). Abstract 207.

Stewart PM \& Krozowski ZS 1999 11ß-Hydroxysteroid dehydrogenase. Vitamins and Hormones 57 249-323.

Stewart MP, Toogood AA \& Tomlinson JW 2001 Growth hormone, insulin-like growth factor-1 and the cortisol-cortisone shuttle. Hormone Research 56 1-6.

Tannin GM, Agarwal AK, Monder C, New MI \& White PC 1991 The human gene for 11 beta-hydroxysteroid dehydrogenase.
Structure, tissue distribution, and chromosomal localization. Journal of Biological Chemistry 266 16653-16658.

Tchirikov M, Kertschanska S \& Schroder HJ 2001 Obstruction of ductus venosus stimulates cell proliferation in organs of fetal sheep. Placenta 22 24-31.

Thorburn GD \& Challis JRG 1979 Endocrine control of parturition. Physiological Reviews 59 863-918.

Tomlinson JW \& Stewart PM 2001 Cortisol metabolism and the role of $11 \beta$-hydroxysteroid dehydrogenase. Bailliere's Clinical Endocrinology and Metabolism 15 61-78.

Wang S, Matthews SG, Jeffray TM, Stevens MY, Yang K, Hammond GL \& Challis JR 1997 The effects of estradiol-17 $\beta$ infusion into fetal sheep in late gestation. Endocrine 6 271-278.

Whittle WL, Holloway AC, Lye SJ, Gibb W \& Challis JRG 2000 Prostaglandin production at the onset of ovine parturition is regulated by both estrogen-independent and estrogen-dependent pathways. Endocrinology 2000141 3783-3791.

Whittle WL, Holloway AC, Lye SJ, Gibb W \& Challis JRG 2001 Glucocorticoid regulation of 15-hydroxy prostaglandin dehydrogenase within ovine intrauterine tissues. Journal of the Society for Gynecologic Investigations 8 (Suppl). Abstract 64.

Whorwood CB, Sheppard MC \& Stewart PM 1993 Licorice inhibits $11 \beta$-hydroxysteroid dehydrogenase messenger ribonucleic acid levels and potentiates glucocorticoid hormone action. Endocrinology 132 2287-2292.

Wood CE \& Srun R 1995 Ontogeny of $11 \beta$-hydroxysteroid dehydrogenase in ovine fetal kidney and lung. Reproduction, Fertility and Development 7 1329-1332.

Yang K 1992 Regulation of gene expression in the ovine fetus. Journal of Reproduction and Fertility Supplement 45 85-95.

Yang K \& Yu M 1994 Evidence for distinct isoforms of $11 \beta$-hydroxysteroid dehydrogenase in the ovine liver and kidney. Journal of Steroid Biochemistry and Molecular Biology 49 245-250.

Yang K, Smith CL, Dales D, Hammond GL \& Challis JRG 1992 Cloning of an ovine 11 $\beta$-hydroxysteroid dehydrogenase complementary deoxyribonucleic acid: tissue and temporal distribution of its messenger ribonucleic acid during fetal and neonatal development. Endocrinology 131 120-126.

Yang K, Berdusco ETM \& Challis JRG 1994 Opposite effects of glucocorticoid on hepatic $11 \beta$-hydroxysteroid dehydrogenase mRNA and activity in fetal and adult sheep. Journal of Endocrinology $143121-126$

Yang K, Yu M \& Han VK 1995 Identification and tissue distribution of a novel variant of $11 \beta$-hydroxysteroid dehydrogenase 1 transcript. Journal of Steroid Biochemistry and Molecular Biology 55 247-253.

Yang K, Langlois DA , Campbell LE, Challis JRG, Krkosek M \& Yu M 1997 Cellular localization and developmental regulation of 11 beta-hydroxysteroid dehydrogenase type 1 (11ß-HSD1) gene expression in ovine placenta. Placenta 18 503-509.

Received in final form 28 October 2002 Accepted 4 November 2002 